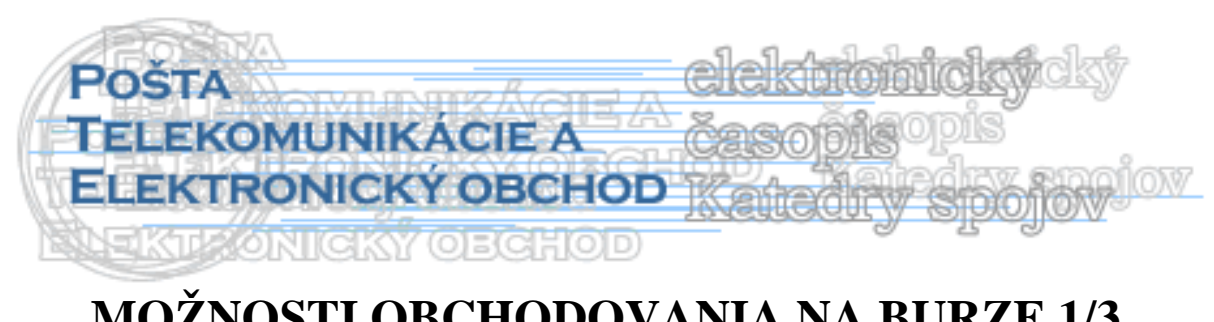

\title{
MOŽNOSTI OBCHODOVANIA NA BURZE 1/3
}

\author{
Zuzana Mičicová*, Martina Kováčiková*
}

Úvod

Burza predstavuje vrcholovú inštitúciu kapitálového trhu. Vo vyspelých krajinách sú burzy neoddelitel'nou súčast'ou trhu a ich činnost' prispieva k tvorbe trhových cien, ale aj k vytváraniu cenového systému aktív.

Vo svete existujú rôzne zamerané burzy, pričom jednou z ich vlastností je to, že sú inštitúciami pôsobiacimi vždy len na verejných trhoch, ktorými sú trhy určitých druhov tovaru alebo služieb, ale aj trhy finančných aktív. Cena tovaru obchodovaného na burze sa nazýva kurz. Prvá čast' článku je venovaná účastníkom burzy, modelom obchodného systému búrz, do ktorého zahrňujeme aj elektronický typ burzy a finančným stratégiám na burzových trhoch.

Účastníkmi burzy sú:

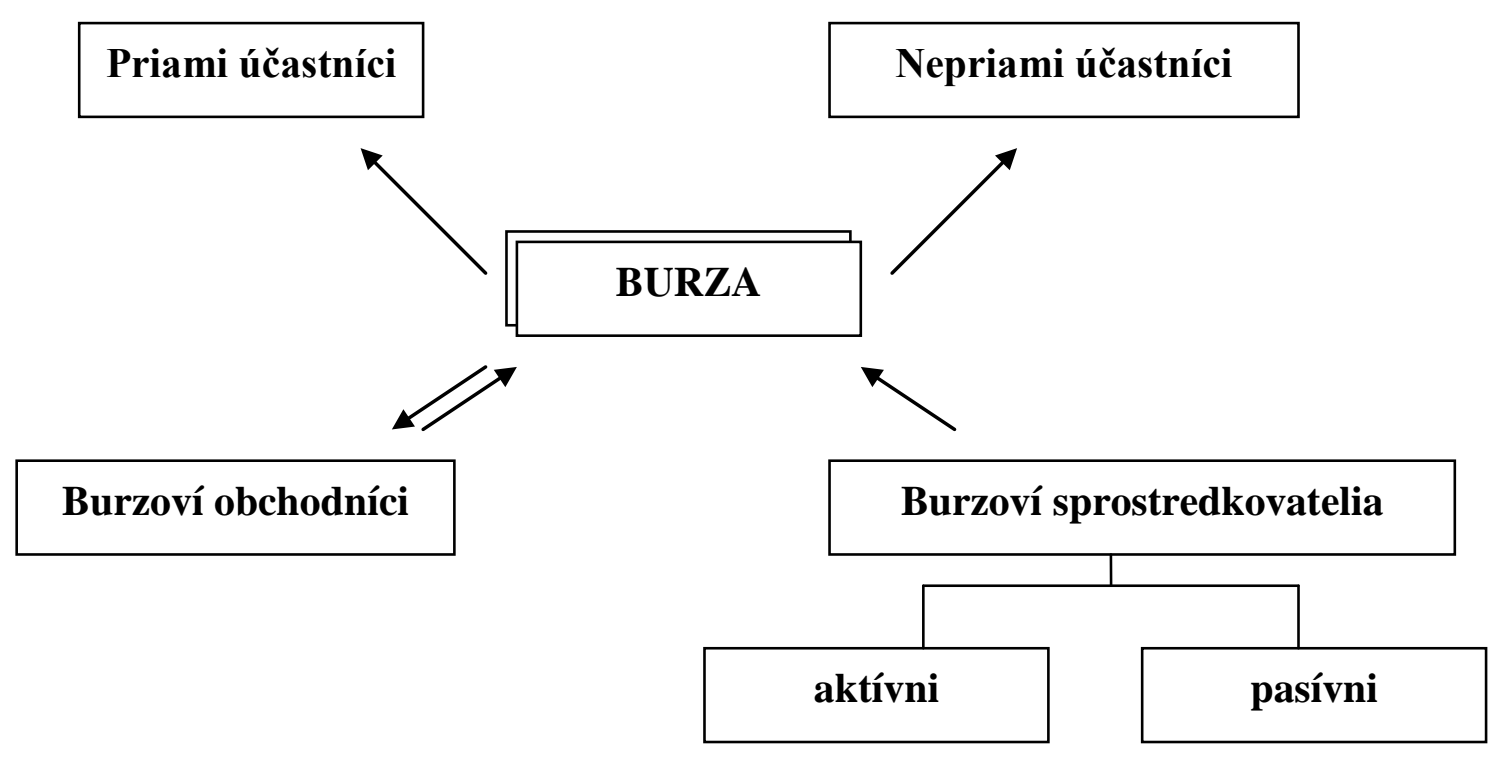

Obrázok 1. Účastníci burzy (Zdroj: vlastné spracovanie)

nepriami účastníci - investori majú záujem kúpit' alebo predat' cenné papiere a využívajú burzových účastníkov, priami účastníci - obchodujú na vlastnom burzovom trhu a realizujú obchody na vlastný alebo cudzí účet,

\footnotetext{
* Ing. Zuzana Mičicová, Žilinská univerzita v Žiline, Fakulta prevádzky a ekonomiky dopravy a spojov, katedra spojov, Univerzitná 1, 01026 Žilina, Slovenská republika, e-mail: zuzana.micicova@fpedas.uniza.sk

* Ing. Martina Kováčiková, PhD., Žilinská univerzita v Žiline, Fakulta prevádzky a ekonomiky dopravy a spojov, katedra spojov, Univerzitná 1, 010 26, tel: +421 415133 123, e-mail: martina.kovacikova@fpedas.uniza.sk
} 
burzoví obchodníci - sú zástupcami členských firemných búrz, burzoví sprostredkovatelia - určujú burzový kurz a uskutočňujú burzové obchody. Môžu byt':

a) aktívni burzoví sprostredkovatelia - oznamujú kúpne a predajné ceny, za ktoré sú ochotní kedykol'vek kúpit' alebo predat' cenné papiere a plnia dve funkcie a to uzatváranie obchodov na cudzí účet (broker) alebo obchodujú na vlastný účet.

b) pasívni burzoví sprostredkovatelia - vykonávajú sprostredkovatel'skú a kurzotvornú funkciu a uskutočňujú burzové obchody. (Obr.1)

- Broker

- je registrovaný sprostredkovatel' pre nákup a predaj finančných produktov, ako sú napríklad komodity alebo akcie,

- okrem nákupu a predaja komodít alebo akcií plní aj nákupné a predajné príkazy, pričom je možné s brokerom konzultovat', radit' sa a pod.

- je potrebné si uvedomit', že v skutočnosti sa nejedná o individuálnu osobu, ale o brokerskú (maklérsku) spoločnost' alebo inú inštitúciu (napr. banku), ktorá brokerské služby poskytuje.

Broker poskytuje rôzne druhy služieb, pričom nie všetky brokerské domy ponúkajú všetky druhy servisu. Tie, ktoré áno, tak môžu mat' tieto služby pomenované inak, pričom základný princíp zostáva rovnaký. Patria sem:

\section{FULL SERVICE}

Ide o službu, pri ktorej okrem toho, že broker plní nákupné a predajné príkazy, je možné s brokerom konzultovat', radit' sa a podobne. Pestrost' full service služieb sa u rôznych brokerských domov výrazne líši. Full service broker obchodníka naučí, ako správne príkazy zadávat’ a dopodrobna ho oboznámi so všetkými možnými druhmi príkazov.

\section{DISCOUNT SERVICE}

Prostredníctvom tejto služby sa brokerovi zadávajú len správne formulované príkazy k nákupu alebo predaji. Žiadne poradenstvo a informácie broker neposkytuje. Obchodníci využívajúci discount servis musia perfektne ovládat' zadávanie príkazov, pretože príkazy nie sú kontrolované a nie je možné ich opravovat'.

\section{ON-LINE SERVICE}

Pri tejto službe obchodník s brokerom neprichádza vôbec do kontaktu. Príkazy sa zadávajú elektronicky cez počítač. K on-line nakupovaniu a predávaniu komodít alebo akcií, stačí len počítač a pripojenie $\mathrm{k}$ internetu. Výhoda on-line obchodovania spočíva $\mathrm{v}$ tom, že príkazy idú priamo z obchodníkovho počítača na obchodný parket, čím sa urýchl'uje predaj a nákup komodít alebo akcií.

Nie všetky brokerské domy ponúkajú všetky druhy servisu. Tie, ktoré áno, môžu mat' každý z týchto druhov služieb inak pomenované, aj ked' základný princíp zostáva vždy rovnaký.

\section{- Interactive Brokers}

- jedná sa o jednu z najznámejších brokerských spoločnosti, ktorá sa špecializuje predovšetkým na obchodovanie elektronických trhov,

- výhodami sú nízke poplatky za službu brokera a prepracovaná modulárna obchodná on-line platforma, 
- pre založenie účtu je potrebné na účet previest' aspoň 10000 dolárov (do roku 2007 to bola čiastka 5000 dolárov.) Užívatel' ma k dispozícií on - line dáta za 10 dolárov/mesiac. Vo chvíli, kedy užívatel' cez platformu aktívne obchoduje a výška poplatkov dosiahne 30 dolárov, poplatok už neplatí. [1]

\section{Modely obchodného systému búrz}

- z technického hl’adiska rozlišujeme 2 základné typy:

\section{a) Prezenčný typ burzy}

- predstavuje klasický burzový systém, obchody sa realizujú na burzovom parkete pomocou „verejného kriku“, kriedy a tabule.

Celá burzová plocha sa delí na:

- Parket - burzový priestor, kde obchodujú priami účastníci burzy. Realizujú sa tu obchody s cennými papiermi, ktoré sú na burzu pripustené a sú kótované v úradnom burzovom lístku.

- Kulisa - predstavuje neoficiálne obchody, na ktorých sa obchoduje s nekótovanými cennými papiermi.

\section{b) Elektronický typ burzy}

- z technologické hl'adiska a z hl'adiska výpočtovej techniky sa neustále mení jej vývoj. Tradičné obchody v burzových sálach sú nahradzované obchodovaniami prostredníctvom výpočtovej techniky. [2]

Burza je trhom tovarov ako každý iný trh, ale má svoje špecifiká a to:

- Obchodovanie na burzách je postavené na princípe obojstrannej aukcie

- význam má v tom, že jeho účastníkom umožňuje priebežne menit' svoje nákupné a predajné obchodné príkazy.

\section{- K burzovému obchodovaniu je vždy potrebné zvláštne povolenie}

- je v ňom presne stanovené, s akými aktívami má príslušná burza právo obchodovat'.

\section{- Predmety obchodu sa fyzicky nenachádzajú na burze}

- predmetom obchodu sú zastupitel'né predmety, ktoré sú určitým spôsobom štandardizované a preto sú vždy navzájom zamenitel'né. Nerastné suroviny, s ktorými sa obchoduje, musia mat' presne vymedzené svoje vlastnosti (napríklad u drahých kovov musí byt' presne vymedzená ich hmotnost', tvrdost', vodivost' a pod.). U cenných papierov sa musí jednat' výhradne o verejne obchodovatel'né a navzájom zastupitel'né cenné papiere, ktoré nesú rovnaké práva.

- Musí byt' presne stanovené najnižšie pripustitel'né obchodovatel’né množstvo

- každá burza musí mat' loty inej vel'kosti, ale musia byt' presne vymedzené nielen pre každú komoditu, ale aj pre cenný papier.

- Čas a miesto burzového obchodovania sú vopred presne určené 
- burzové obchody sa konajú pravidelne v určitú dobu a na určenom mieste, k čomu slúži burzový kalendár. Vopred sú presne určené aj burzové hodiny, mimo ktorých nie je možné na burze obchodovat'.

- Obchodom na burze sa smie zúčastnit’ presne vymedzený okruh osôb

- každá burza má vo svojich predpisoch stanovené pravidlá pre určené osoby a inštitúcie, ktoré sú priamymi účastníkmi trhu. Konkrétne sa jedná bud' o burzových obchodníkov, ktorí zastupujú členské firmy alebo o burzových sprostredkovatel'ov, ktorí sú burzou menovaní.

\section{Finančné stratégie na burzových trhoch} má 2 ciele:

Vstup investora a jeho investovanie s účelom získavania finančných nástrojov a aktív

- maximalizácia zisku,

- minimalizácia rizika.

Maximálne naplnenie oboch ciel'ov nie je možné uplatnit', preto sa hl'adajú možné riešenia, ktoré vytvárajú kompromis medzi spomínanými ciel'mi. Výsledkom týchto riešení sú stratégie zamerané na dosahovanie zisku (tradingové, arbitrážne a pod.) alebo prednostne zamerané na znižovanie rizika (hedgingové, stratégie zabezpečovania hodnoty portfólia cenných papierov.)

\section{Tradingové stratégie}

- majú predovšetkým špekulačný charakter, špekuláciou sa rozumie aktivita, ktorá v záujme očakávaných budúcich ziskov akceptuje riziko, že možnost' straty je vyššia ako primeraná,

- ich iniciátor sa snaží maximalizovat' zisk a súčasne minimalizovat' jej riziko.

- tvorca tradingovej stratégie sleduje ako prvoradý ciel’ zisk z prevádzaných operácií.

\section{Členenie tradingových stratégií:}

- $\quad$ singulárne - subjekt kupuje alebo predáva podkladové finančné aktívum alebo derivát s ciel'om dosiahnut' zisk. Ide o samostatnú operáciu, ktorá je oddelená od inej transakcie,

- kombinované - súčasne sa vykonávajú viaceré transakcie

\section{Arbitrážne stratégie}

- arbitráž predstavuje dosahovanie zisku využívaním cenových rozdielov rovnakého aktíva alebo nástroja obchodovania na dvoch alebo viacerých trhoch,

- arbitražér kúpi príslušné aktívum alebo nástroj na trhu, kde je jeho cena nižšia a predá na trhu, kde je jeho cena vyššia. Pretože obe transakcie prebiehajú v rovnakom čase nesie arbitražér len minimálne riziko. Arbitrážne stratégie môžeme členit' na:

\section{Bezriziková arbitráž}

a) cenové rozdiely medzi jednotlivými promptnými trhmi

- pri cenných papieroch vznikajú arbitrážne možnosti, ak je cenný papier kótovaný na dvoch alebo viacerých burzách, a ked' sa kurz cenného papiera na jednotlivých trhoch odlišuje. Obchod sa oplatí vtedy, ak je kurzový rozdiel vyšší ako náklady spojené s transakciou.

b) rozdiel medzi menami na promptnom a termínovom trhu:

- arbitráž cash and carry (kúp a prenes do budúcnosti) - ak je cena termínovaného kontraktu nadhodnotená v porovnaní s promptnou cenou 
daného aktíva. Vtedy arbitražér kúpi dané aktívum na promptnom trhu a súčasne predá futuritu na dané aktívum,

- reverzná arbitráž cash and carry - ked' je situácia na trhu obrátená, to znamená, že cena terminovaného kontraktu príslušného podkladového aktíva je podhodnotená v porovnaní s jeho promptnou cenou. Vtedy arbitražér predá podkladové aktívum „nakrátko“ (požičia si ho a predá), a súčasne kúpi futuritu na dané aktívum. Okrem futurít sa využívajú aj opcie,

- rozdiely medzi cenami jednotlivých nástrojov na termínovanom trhu prichádza do úvahy, ak sa objavia rozdiely pri ocenení rôznych nástrojov na jednom termínovanom trhu, pri ocenení rovnakého finančného nástroja na dvoch a viacerých trhoch (zemepisná arbitráž).

\section{Riziková arbitráž}

- predstavuje napríklad kúpu akcií spoločnosti, ktorá má byt’ prevzatá preberajúcou spoločnost'ou, a súčasný predaj akcií preberajúcej spoločnosti,

- ide o fúziu dvoch spoločnosti, kde je jedna akciová spoločnost' silnejšia a pohlcuje druhú, ktorá je slabšia.

- prevzatie sa môže uskutočnit' na základe dohody alebo nákupom väčšiny akcií (majority) preberanej spoločnosti bez súhlasu vedenia. V oboch prípadoch sa dopyt po akciách zvyšuje.

\section{Tvorba portfólia}

1. sústredenie údajov (výnosnost'),

2. rozhodovanie o zaradení jednotlivých aktív do portfólia (strategická diverzifikácia druhy aktív, krajina pôvodu, mena + taktická diverzifikácia - konštrukcia efektívnych portfólií),

3. výber optimálneho portfólia - individuálny proces pre každého investora.

\section{Pri tvorbe portfólia je nutné odlišovat' portfólio:}

- trhové - zostavené zo všetkých cenných papierov, ktoré sú k dispozícií na kapitálovom trhu a v proporciách, v akých sú tieto cenné papiere zastúpené na trhu. Výnosnost' sa potom rovná priemernej výnosnosti všetkých cenných papierov na trhu,

- efektívne - má dve charakteristiky a to pri rovnakej rendite vyjadrujúcej výnosnost', neexistuje na trhu portfólio s nižšsu rizikovost'ou. Pri rovnakej rizikovosti neexistuje portfólio s vyššou renditou,

- optimálne - je také efektívne portfólio, aké si investor zvolil s ohl’adom na svoj vzt'ah k riziku. Portfólio môže byt' označené za konkrétne len z hl'adiska konkrétneho investora.

\section{Hedgingové stratégie}

- Hedgingové stratégie sú významnou súčast'ou rizikového manažmentu podniku. Pojmom „hedging“ rozumieme zmierňovanie, rozkladanie a prenášanie podnikových finančných rizík na iné subjekty,

- základnými nástrojmi hedgingu sú finančné deriváty. Likvidovanie rizík sa zabezpečuje zaujatím takých derivátových pozícií, ktoré po určitý čas chránia súčasnú hodnotu podnikových aktív (resp. pasív), alebo umožňujú podniku profitovat' z časovo ohraničenej budúcnosti zo súčasnej hodnoty istých aktív (resp. pasív),

- hedging je možné prirovnat' k poisteniu, avšak je tu zásadný rozdiel. Pri poistení dochádza k rozloženiu rizika na vel'kú skupinu poistencov, kým hedging neznižuje 
riziko, ide len o prenesenie rizika nepredvídatel’ných zmien $\mathrm{z}$ jedného investora (inštitúcie) na druhého. [3]

\section{Záver}

Burza je vrcholový trh, ktorého vznik je spojený s rozvojom obchodnej činnosti. Základom burzovej činnosti sa stali pravidelné schôdzky obchodníkov na určitých miestach, kde sa určovali podmienky obchodu.. Názov burza je odvodený od mena holandskej rodiny Van Der Burse, u ktorej sa stretávali v dome obchodníci a uzatvárali tu obchody. Ich obchod bol označený 3 mešcami. Z toho dôvodu sa zaviedol aj pojem burza len vanglickej terminológii (The Exchange).

Burza ako ekonomická kategória je zvláštnou formou trhu a má rôzne charakteristické znaky. Burzový obchod nie je vzt'ahom medzi účastníkmi burzového trhu, ale zmluva, ktorú spolu títo účastníci uzatvárajú. Táto zmluva vykazuje určité špecifické znaky, ktoré sú vymedzené právom.

Burzový obchod chápeme ako druh právneho konania, jeho špecifiká a charakteristické znaky vyplývajú z toho, že sa burzový obchod uskutočňuje na zvláštnom trhu. Preto možno burzový obchod definovat' tak, že ide o zmluvu uzavretú na burzovom trhu. Zmluvu, ktorej obsahom je kúpa alebo predaj tovaru uzavretá na burze, môžeme označit' ako hlavný burzový obchod. Zmluvu uzatvorenú na burze odlišujú od ostatných zmlúv určité znaky: sú dané subjektmi, tovarom, miestom uzavretia zmluvy a zmluvnými podmienkami. Vzhl'adom na činnost' burzy môžu na ňu vstúpit' len tí, ktorí majú povolenie od burzových orgánov. Podl'a jednotlivých búrz a ich špecifík môžeme tiež hovorit', že burzové orgány presne definujú, ktoré osoby resp. inštitúcie majú na burzu prístup.

\section{Literatúra}

[1] DOSTUPNÉ NA: http://www.financnik.cz/wiki/broker

[2] DOSTUPNÉ NA: http://www.euroekonom.sk/financie/burzy/burzovy-system/

[3] MIČICOVÁ, Z.: Možnosti investovania finančných prostriedkov do vybraných podkladových aktív kapitálového trhu - index, komodita, diplomová práca, Katedra spojov, Žilinská univerzita v Žiline, 2009 